\title{
Institutional preconditions for the collective capacity to act in urban areas: a QCA of seventeen European case studies
}

\author{
Fritz Sager
}

\begin{abstract}
The present article questions the institutional preconditions for solving problems of interdependency in urban areas. Policy coordination in terms of processes as well as outcomes serves as an indicator for the collective capacity to act. Hypotheses are derived from two institutionalist schools: first, from the neoprogressive model that stands for direct public service provision by centralized and professionalised bureaucracies within consolidated municipalities, and second, from the public choice model that represents a decentralized, non-professional, and politically dependent administration in fragmented urban areas. The results of the comparison of seventeen case studies regarding the integration of urban transport and land use policies in Western European urban areas employing Qualitative Comparative Analysis (QCA) show that well co-ordinated policy decisions are only implemented in institutional settings that largely correspond to the neoprogressive model.
\end{abstract}

Keywords: Qualitative Comparative Analysis (QCA) · Urban areas · Policy coordination · Neo-institutionalism $\cdot$ Collective capacity to act

\section{Institutionelle Bedingungen kollektiver Handlungsfähigkeit im urbanen Raum: Eine QCA von siebzehn europäischen Entscheidungsfällen}

Zusammenfassung: Der vorliegende Aufsatz fragt nach den institutionellen Bedingungen für die Bewältigung von Interdependenzproblemen im urbanen Raum. Als Messgrösse für kollektive Handlungsfähigkeit wird die Qualität von Politikkoordination im Prozess und im Entscheidungsergebnis gewählt. Für die empirische Untersuchung werden zwei einander entgegen gesetzte verwaltungswissenschaftliche Modelle metropolitaner Institutionen hergeleitet und Hypothesen formuliert: Einerseits steht das neoprogressive Modell für Zentralisierung, konsolidierte Raumstrukturen sowie eine professionelle und politisch unabhängige Verwaltung. Andererseits steht das Public Choice-Modell für Dezentralisierung, fragmentierte Raumstrukturen sowie eine un-

\author{
Published online: 14.01 .2010 \\ (C) VS-Verlag 2009 \\ Prof. Dr. F. Sager $(\bowtie)$ \\ Assistant Professor for Policy Analysis and Evaluation \\ Center of Competence for Public Management, University of Bern \\ Schanzeneckstrasse 1, P.O. Box 8573, CH-Bern, Switzerland \\ Tel.: +41 $31631-3285$ \\ Fax: $+4141631-5317$ \\ e-mail: fritz.sager@kpm.unibe.ch \\ www.kpm.unibe.ch
}


professionelle und politisch abhängige Verwaltung. Die Resultate des Vergleichs von siebzehn Fallstudien zu raumwirksamen Entscheidungsprozessen in westeuropäischen Stadträumen mithilfe Qualitative Comparative Analysis (QCA) weisen die neoprogressiven Postulate als leistungsfähiger für Politikkoordination aus als das Public Choice-Modell.

Schlüsselwörter: Qualitative Comparative Analysis (QCA) · urbane Räume · Politikkoordination · Neo-Institutionalismus · kollektive Handlungsfähigkeit

\section{Introduction}

Western European urban areas are increasingly confronted with a dualistic pressure. On the one hand, a trend towards economical and demographical concentration consists in the so-called metropolitan areas. These gain economical, social and cultural importance due to international competition. The problem-solving competences of these conurbations in respect of formal policy do not correspond to their problems regarding the formulation and realization of policy. A united front consisting both of urban and rural areas towards superior state-levels can be regarded as one solution. On the other hand, an increasing tendency towards fragmentation within urban conurbations could prevent a necessary and requested inner unity. Moreover, the migration from core municipalities is distinguished by contrary, self-amplified mechanisms, causing a vicious circle of urban sprawl: the more people migrate to rural areas, the less attractive the core municipalities become. In consequence, even more people migrate. Due to this particular situation, urban areas are confronted with a special call for action. A deadlock threatens because of cumulating problems within the metropolitan areas combined with the development of large-scaled centers of power and growing international competition. This may obstruct both the internal and external latitude. The solution is generally seen in a cross-sectional cooperation between urban and rural areas, aiming at coordinating political programs in different fields of policy (Benz 1994; Blatter 2005; Heinz 2000; Le Galès 1998; Sager 2002).

Core municipalities and surrounding rural areas are thus faced with the problem of the collective capacity to act. There is a specific need for "modes coping with interdependencies, which aim at the restoration and stabilization of a collective capacity to act for a majority of individual players" (Schimank 2002, p. 31). It will be argued in the following that the coordination of policy proves to be a suitable measurement for the collective capacity to act. Two competing hypotheses are derived from two different institutionalist schools of metropolitan institutions, which will both be used to define policy coordination. The neoprogressive model relates to Weber's (1972) analysis of bureaucracy and is associated with the sociological institutionalism of "bounded rationality" (Jones 2003). The public choice model is associated with the economical institutionalism (Ostrom and Ostrom 1971). The analysis focuses on the structures of public administration, being the most crucial form of social institutions of modern society (Zucker 1983, p. 1). The essay is structured as follows:

The next section deals with intellectually positioning and discussing the two different approaches, the neoprogressive and the public choice school. The section after that will present the problem of policy coordination to question the collective capacity to act, and as a dependent factor for the empirical analysis, and will conclude with the hypotheses. 
The then following section introduces the research strategy, the case choices, the method of the empirical studies to be examined and the operationalisation of the variables. The subsequent empirical analysis consists of the systematic comparison of seventeen case studies pertaining to policy coordination in Western European urban areas. This will be based on the macro-qualitative method of the Qualitative Comparative Analysis (QCA) ${ }^{1}$. This method is applicable for the present analysis, since, on the one hand, it is especially suited for a medium range of case studies; on the other hand, the focus is not on isolated effects of singular variables, nor of conditions, in terms of QCA, but rather on combined effects of different values and conditions. The deduction consists of a summarizing appreciation of the cognizance.

\section{Two models of metropolitan institutions}

As Krücken (2002, p. 227) ascertains, a "rediscovery of institutionalized concepts is to be observed within the disciplinary triangle of sociology, political science and economics" since the 1980's. This neo-institutionalism is based on the interface of organizational, economical and networking research (Powell and DiMaggio 1991). The present analysis utilizes the trend which "primarily serves as a generator of theory of medium range in present research" (Krücken 2002) to question the institutional preconditions for successful policy coordination. Based on the research of Scott and Meyer (1991), four central dimensions of organization are identified as being relevant for the social and political behavior and for political decision making within organizations: (1) centralization versus decentralization, (2) urban consolidation versus urban fragmentation, (3) professionalization versus non-professional administration, and (4) autonomic administration versus politically dependent administration.

Based on the literature, two institutional designs will be extracted along these four dimensions, which can be postulated on the basis of the schools of the progressive reformers and of the public choice model.

2.1 Neoprogressive model: centralization, consolidation, professionally and politically independent administration

The US-American school of the progressive reformers evolved out of the discontentment over corrupt regimes in American cities in the late $19^{\text {th }}$ century. The reoccurring postulates of the Progressive Movement in the administrative science discussion during the 1990's (Hill 1991; Goodsell 1994) were a response to the triumph of the public choice concept. The supporters of Lowery's (1999) newly labeled "neoprogressive" school particularly encounter the fundamental public choice argument concerning state failure with

1 Even though the number of users of the QCA-method is increasing in international research (compare the internet platform http://compass.org/), only few studies employ the advantages of this approach in the German Language Area (Berg-Schlosser and Quenter 1996; Obinger 1998; Sager 2002). The discussion is otherwise limited to essays in methodological school literature (Berg-Schlosser 1997; Wagschal 1999; Schneider and Wagemann 2007). 
the understanding that the market instruments fail in several public fields. Recent studies recognize both the theoretical argument and the empirical success of the public choice model, and demand a differentiated debate, which basically amounts to renewing the concept of the administrative model of the Progressive Movement (Lowery 1999, p. 47; Sager 2005).

The institutional model, which represents the neoprogressive school, can be described with the following four hypothetical postulates within the analytical dimensions of Scott and Meyer (1991): centralization, consolidation, professionalization and autonomy.

- The centralization postulate basically corresponds to Weber's rational bureaucracy model containing the element of hierarchical structure (Weber 1972). A tendency of centralization exists due to the fact that the higher levels control the subordinated levels, and that the governing bodies are organized monocratically and not collegially. Due to intensified organizational control, more standardized and calculated performance is achieved and work-sharing differentiation encouraged. This system optimizes the synoptic capacities of administration and avoids bureaucratic arbitrariness on different levels, thus increasing the efficiency of public acting through scale effects and the omission of coordination costs (Nigro and Nigro 1989, p. 110).

- The argument of urban consolidation is crucial in the neoprogressive argumentation. Keating (1995, p. 118-123) refers to four lines of argumentation: (1) efficiency, (2) democracy, (3) equality of distribution and (4) urban development. The argument of efficiency is primarily based on an economical point of view. Minimal project size, accruing costs of coordination in fragmented areas and decreasing average costs are arguments speaking for consolidation (cf. Wittek and Flache 2002, p. 62 regarding the transaction costs theory). The argument of democracy states, on the one hand, that large urban units appear stronger confronting superior state levels. On the other hand, the comparative analysis of Lyons et al. (1992) concludes that minorities participate more in consolidated units and are better informed about political structures in their community, contrary to residents of fragmented systems. The argument of distribution postulates that consolidated areal units lead to more justice of distribution, resulting in a greater contentment of its residents, as opposed to fragmented conurbations. Finally, the argument of development states that consolidated urban unities enhance the competitive position of the overall area, thus ensuring economical development.

- The postulate of professionalism founds in the belief of the progressive reformers (West 1995, p. 5) in technology and modernization. From the outset, it manifests itself in the demand for well-educated and specialized knowhow for the well-being of society, respectively for the administration. Planning literature of the 1960's uses the criteria of professional specialization and differentiation to attribute the advantages of functional differentiation concerning the cognitive preconditions for cooperative action (Nigro and Nigro 1989, p. 110; Simon 1962). One can refer to the concept of epistemic community (Haas 1964), which was primarily developed for the analysis of international negotiations. An epistemic community consists of a network of professional experts in specific fields of policy, whose knowledge of particular policy contents is of central relevance (Haas 1992, p. 3). The generated and reproduced 
knowledge, achieved by mutual education and mutual professional values, leads to a cross-bordered, sectoral consensus of these players. Since a rational, political result is the goal, and not the appeasement of particular interests, such professional values lead to a consensual cross-bordered coordination of policy.

- The postulate of political independence roots in one of the founder writings of the progressive movement, in which Wilson (1887) names the lack of separating political and administrative areas as the root of corruption and injustice. The term autonomy applies to the political administration as a stand-alone partner of negotiation within the political process. Autonomy is meant in terms of corresponding to the political administration's own political latitude, which is defined by a clear delimitation of competences from legislature. It is therefore a matter of a limited political capacity for action, being protected from outside influences. Such interventions can not only result from singular interferences through legislature, but also from the influence of economical and social singular interests, or from the participation of politically concerned parties. A high-level autonomy of administration counteracts the neutralization of expert knowledge through political influence, thus enabling problem-related coordination of public action (Wolf 1993).

The public choice model presented in the following section stands fully contrary to these postulates:

\subsection{Public choice: decentralization, fragmentation, non-professional and politically dependent administration}

With their essay "Public choice: A Different Approach to Public Administration" from 1971 (Ostrom and Ostrom 1971), Elinor and Vincent Ostrom broke with the almost 100 year-old progressive dominance in American administration science. The newly postulated, political-economical understanding of administration contained new paradigms. They were part of an extensive sociological concept of the rational choice theory, which posed "a radical and provocative program for the research of organizations in their orthodox form" (Wittek and Flache 2002, p. 55, also Hay 2004).

The principle line of argument of the public choice model in administration can be summarized following the premises of the economical theory of policy (Downs 1957): every form of state intervention in society hinders the development of the free market and thus opposes the basic right of each individual for benefit maximization. This restriction is pejorative, since, according to the principle of individuality, the welfare of a society corresponds with the sum of the welfare of all of its individuals by means of rational benefit maximization. The administration is the central responsible body of state interventions and therefore contradicts the principle of the free market. Even more, it reinforces government interference due to the system-immanent vicious circle. Individual officials primarily wish to maximize their budgets in accordance with the axiom of self-interest, hence causing an increasing government share, causing interventions, respectively backbonding the individual capacity for action (Niskanen 1971). Public administration thus fails as a system, not only in its task of appeasing its citizens (state failure), but also in being non-democratic at the same time. Thus, the public choice model generally stands 
for a small-scale administration to confound hindering the market. The postulate stating that certain organizational structures lead to coordination is derived from the argument that individual striving for the best possible achievement of personal goals "can lead to cooperation, if individual social players are functionally dependent of each other, thus needing one another to achieve their own personal goals. (...) Individuals acting upon rational action cooperate, because they generate obligations which can be reclaimed later on in accordance with the principle of reciprocity" (Wittek and Flache 2002, p. 75).

Within this goal, along the chosen dimensions of analysis, the institutional model of public choice can be characterized with the following central postulates in form of hypotheses: decentralization, fragmentation, generalist administration and direct political dependency.

- With the decentralization of organizational structures, combined with an increase of autonomy of the thus created unities, more self-reliance and responsibility is delegated to the "frontline", which orientates itself much more towards the citizen, or customer, than does the central administration. The loss of operative control options is compensated by an amplified strategic management and by appropriate quality guidelines from the politically responsible authorities. Decentralization has the advantage of having numerous benchmarks, which can help to measure the performance of each administration unit (Schedler 1995, p. 95). While the advantages are an improvement in the gratification for its citizens, which leads to an increase in common welfare following the logics of economy, Budäus (1994, p. 56) summarizes the positive effects of decentralized structures for the public administration as follows: complexity is reduced and administrative operations become more transparent, because performance and costs can be clearly allocated. Consolidating the responsibility of each field and of the resources leads to a congruence of decision-making and responsibility for its consequences, whereby mechanisms of coordination, similar to competition, can be institutionalized within the administration.

- Closely related to the postulate of decentralization is that of urban fragmentation, the argument of efficiency being central. Tiebout (1956) sees local governments as enterprises and its citizens as consumers. Accordingly, local governments try to offer their services to the lowest possible price, as desired by their citizens. These choose their district out of a combination of services and tax burdens, which are most in accordance with their preferences (Tiebout 1956, p. 420). The more providers of public goods exist, the more likely market conditions develop, which will lead to gratification of individual needs and to an efficiency improvement of the supplies due to competition. One flaw of Tiebout's model (1956) is his basic assumption that, first of all, mobility is free of costs, and, secondly, that job markets are insignificant. Further developments of the Tiebout Model question the conditions under which an individual "can shop around for services" (Tiebout 1956) without having to move away, and how these conditions can be established by inter-communal competition. Ostrom et al. (1988) argue that urban fragmentation and competition between local governments increase the allocative efficiency due to assets being transferred to those areas in which they can be employed in the most productive manner. A second argument of the public choice model is the fortification of the principles of democracy in the sense 
of direct gratification of individual political preferences. It is argued that democracy is stronger the nearer politics is to its citizens.

- The postulate of a non-professional administration, as that of a politically dependent one, are both derived from the consideration that individual gratification will be all the more fulfilled the less of a distance lies between the citizens and the administrative office offering certain public goods. This distance exists due to specialized expertise, or a lack of political control mechanisms and with autonomic scopes for action. The preponderance of specialized criteria at the loss of considering the actual demand while producing a public good should be countervailed by breaking up the hierarchical division of labor (Obsorne and Gaebler 1992, p. 47). Goal targeting in place of process control leads to different demands posed on the officials. Not the specialized responsible bodies of isolated functions will be needed in offices with "missions", but rather broad-ranged generalists who are partially able to perform occasional sectoral coordination. With the declining of professionalization individual preferences will be less distorted with superordinated specialist concepts and will therefore be more gratified.

- The postulate of a greatest possible politicized public service, meaning not appointed, but from the citizens concerned, or from their legitimate representatives elected service, arises from the will to gratify individual citizen preferences as directly as possible (Osborne and Gaebler 1992, p. 47). The solution of the public choice school lies in keeping the administration as small-sized as possible, and in putting it under the control of direct democracy (Kettl 2000; Lane 2000). The administration's connection to democratic decision-making in order to be able to react quickly towards arising needs will be obligatory when officials are dependent on the voters' goodwill. Because deselection threatens by not fulfilling the majority of individual needs in this particular case. Political independence does not only increase the democratic legitimacy of an administration, but it also improves its service in terms of the collective as a sum of its parts.

\section{Policy coordination as a mean to measure the collective capacity to act and hypotheses}

As mentioned in the introduction, policy coordination is a central challenge to urban areas. It is the dependent variable of this analysis, respectively, according to QCA-Terminology, the result to be verified. Fritz W. Scharpf $(1972,1991,1992,1993,1994,1997)$ has been dealing with the issue of policy coordination since the 1970's. Scharpf understands policy coordination as a concept of theoretical welfare: "Forms of reconciliation" are to be described, "whose welfare-theoretical high standards exceed the attainable (...) balance achieved by that of reciprocal anticipation in non-cooperative games". In order to be a welfare-theoretical concept, policy coordination needs a clear, normative reference. The Pareto principle is the economical benchmark of welfare. It attests allocative efficiency to a solution "if no other solution is possible which would increase the benefit of at least one participant without another being disadvantaged in that course" (Scharpf 1992, p. 15). The "sheer abdication of unnecessary benefit circumvention" (Scharpf 1991, 
p. 624) is, however, insufficient for an evaluation under a political science point of view. This is due to the fact that policy can disparately intervene in the market's achievements, and is interested not only in welfare-theoretical efficiency, but also in distribution justice of the solutions found.

Scharpf (1991, p. 624) describes the criterion of Kaldor (Kaldor 1939) as being a "better approach to a politically relevant term of welfare, as it evaluates all measures positively, whose use for the beneficiary is large enough to compensate all who are at disadvantage because of them. The normative issue of distribution justice is more easily solved in a Kaldor optimum as in solutions which are only Pareto-optimal. Contrary to the Pareto optimum, there is room for political distribution processes within Kaldor-optimal solutions.

According to Scharpf (1994, p. 28), the coordination dilemma is that Kaldor-optimal solutions are only successful in perfect hierarchies, or in perfect negotiations. Both forms of coordination have the disadvantage of losing their efficiency as soon as ideal conditions are not fulfilled, they therefore do not occur in reality. So the "games real actors play" (Scharpf 1997) occur aside of these ideal types. There are rather more institutionally embedded forms of self-coordination which oscillate as hybrid forms between these two ideal types. For the empirical description and evaluation of these forms of "negotiations in the shadows of hierarchy" (Scharpf 1972), four aspects will be analyzed in the following: Firstly the occurrence of coordination, secondly the quality of coordination processes, thirdly the quality of coordination results, and fourthly the actual implementation of the solution.

As listed above, the occurrence of coordination is chosen to be the first dependent variable, concretely referring to aligning options of acting for all players involved in a mutual problem-solving process.

The second dependent variable is the formal rationality of coordination processes. While in the positive coordination new projects are multilaterally coordinated with all options of acting of all departments involved, the negative coordination, in an anticipative and bilateral manner, restricts all new projects to options not currently disposable, but compatible with accessible positions of all involved (Scharpf 1993). Based on the argumentation of Scharpf (1993, 1994, 1997), stating that a negotiation obtains results closer to the Kaldor optimum the more compatible policy options are aligned, and the more consensual it is, a coordination process is described as being formal and rational when it is voluntary and multilateral, respectively when it coordinates positively and is rational in acting. Hybrid systems of negotiation processes are signified as formal, majorly rational (e.g. constraint negotiation, positive coordination and rationality of power). A formal, majorly non-rational process is negotiated under constraint, is bilaterally, or negatively coordinated and is of rational power. Unilateral decrees and a complete lack of coordination are signified as formal non-rational.

The Kaldor optimum is chosen to be the third dependent variable. Since it is a sheer theoretical construct, the coefficient must be modified. For this purpose, the term of substantial rationality will be implemented. In the following, an urban project will be described as being "substantially rational" when referring to a convergence to the Kaldor optimum. Partially substantial rationality refers merely to Pareto-superiority, which means that the use for the benefactors suffices only partially, not entirely compensating 
for the "loser", whereas a lack of substantial rationality, or no coordination, refers to the Pareto optimum.

A coordinated outcome is of little practical value if it will not actually be realized. In order to evaluate the coordination quality as a measure of the collective capacity to act, it therefore has to be taken into account whether an outcome will be politically accepted, which is necessary for its implementation. The implementation of the planning itself, meaning the constructive realization of a project, is therefore the fourth dependent variable.

On the basis of both models presented in the theoretical section the following hypotheses can be formulated to explain the success of coordination, the neoprogressive presumptions $(n p)$ and the public choice expectations $(p c)$ being mutually contradictory.

H1np: centralized administrative management ensures successful coordination of policy. $H 1 p c$ : decentralized administrative management ensures successful coordination of policy.

H2np: consolidated urban areas ensure successful coordination of policy.

$H 2 p c$ : fragmented urban areas ensure successful coordination of policy.

H3np: districts with a highly professionalized and specialized administration ensure successful coordination of policy.

H3pc: non-professional generalist administration ensures successful coordination of policy.

H4np: politically autonomic administration ensures successful coordination of policy.

$H 4 p c$ : politically dependent administration ensures successful coordination of policy.

\section{Research frame, case choices, methods, operationalisation and data}

A so-called meta-analysis of seventeen case-studies on urban structure policy in nine Western European countries will be conducted for the empirical verification of the postulated institutional effects. Meta-analyses describe the quantitative refurbishment of existing studies whose results are commonly presented in numerical form. The idea is that for the empirical approach to a theoretical issue, the analysis of existing studies can lead to a perception going beyond the mere results and experiences of these individual studies (Wolf 1986; Hunter and Schmidt 1990). Additionally, methodological flaws of individual studies can be eliminated and results of great credibility can be achieved by aggregating the results. Particularly, potential sources of error caused by lacking sample size of individual studies can be partially minimized (Glass et al. 1994). Since the questions dealt with affect modes of action which can only be analyzed by a diachronic analysis of the entire process procedures, a quantitative examination with qualitative case-by-case analyses will be performed in the present analysis. A very similar research strategy is used by Nijkamp et al. (2002). Their meta-analysis of urban revitalization projects in the Netherlands is based on ex post coded qualitative case studies.

One central problem of meta-analyses is the validity which can be affected due to the heterogeneity of the chosen cases. This problem will be dealt with in the present research frame in two ways: Firstly, with a founded choice of cases with distinct criteria, and, 
secondly, with a homogenous coding of the qualitative case studies along the following operationalisation (Tables 2 and 3). The target population of the present study consisted of all at that point available studies dealing with coordinating spatially relevant political fields in urban areas from a sociological point of view. In order to be included in the target population, a study had to fulfil four criteria: it had to analyse a Western European metropolitan area; it had to examine a case method dealing with the coordination of spatial and transport policy. It had to allow for coding along the presented operationalisation; and it had to fulfil certain formal scientific criteria. These case choice criteria will be briefly presented in the following section:

First of all, the studies had to focus on cases dealing with Western European urban areas. The limitation to Western Europe allows for the dispersion of institutional variables, which is essential for the analysis because different national administrative and governmental cultures (Knill 1999; Lefèvre 1998; Raphael 2000). And, at the same time, the limitation offers a specific historical and cultural frame (Caramani 2005; Kaelble 2002), distinguishing it from other world regions. Different cultural, historical and politically systemic variables can thereby be controlled, and a basic comparability of the cases is ensured.

Secondly, the cases had to pertain to the same fields of policy in order to avoid distortion due to singularities in different political fields. The problem of urban sprawl is primarily a problem of increasing social and geographical mobility. With increasing economic wealth, urban residents move to the suburbs while their place of employment usually remains the same, thus prolonging the journey to work. Consequently, the volume of motorized private transport increases, since the public transport infrastructure is less well-developed in the less populated rural areas. This, in turn, primarily affects the standard of living in the core municipalities, making the rural areas even more attractive. The theoretical solution for urban areas lies in long-term re-urbanization. This means an ecologically, socially and economically compatible converse in urban sprawl tendencies. The two regionally significant fields of policy, urban and transport planning, play a central part in this multifarious task, in which urban sprawl mainly constitutes a spatial problem. More precisely, it will be necessary to resettle housing space, business and service enterprises to train stations and other junctions of public transport and road networks. This is implied by the cross-bordered coordination of spatial and transport policy (Dijst and Schenkel 2002; Holz-Rau and Jansen 2007; Janssen-Jansen 2005; Kaufmann and Sager 2006; Sager 2002).

Spatial and transport planning can therefore be seen as suitable test cases for examining policy coordination.

Thirdly, the case studies had to contain an analysis, or at least a description of institutional variables which stand in the center of this analysis. And the case study had to evaluate the coordination process, or rather its result.

And finally, fourthly, the formal criteria of Wolf (1993, p. 166) were applied for the choice of case studies. In order to be considered, a case study had to be based on empirical data, not on a model calculation. It had to contain a minimum of fifteen pages of analysis to allow for a founded encoding, a biography and references, and was not allowed to be produced by participants of the case being analysed. 
Table 1: The selected case studies

\begin{tabular}{|c|c|c|}
\hline Case study & Country & Reference \\
\hline 1. Mobility plan in Flanders & Belgium & Steenberghen 2000 \\
\hline $\begin{array}{l}\text { 2. Öresund-connection from Kopenhagen and } \\
\text { Malmö }\end{array}$ & Denmark/Sweden & Matthiessen 2000 \\
\hline 3. Kopenhagen Metro & Denmark & Matthiessen 2000 \\
\hline 4. Traffic concept in Freiburg & Germany & Bratzel 1999 \\
\hline 5. Agglomerational transport planning in Marseille & France & Margail and Offner 2000 \\
\hline 6. Agglomerational transport planning in Toulouse & France & Margail and Offner 2000 \\
\hline 7. Agglomerational transport planning in Orléans & France & Margail and Offner 2000 \\
\hline 8. Urban development planning in Newcastle & Great Britain & Guy et al. 2000 \\
\hline 9. Planning agreement in Saronno & Italy & Morandi et al. 2000 \\
\hline 10. Integrated urban development planning in Rome & Italy & Sessa and Gualdi 2000 \\
\hline $\begin{array}{l}\text { 11. Development planning for the agglomeration } \\
\text { Groningen }\end{array}$ & Netherlands & Voogd 2000 \\
\hline 12. Transport concept in Amsterdam & Netherlands & Bratzel 1999 \\
\hline 13. City tunnel in Malmö & Sweden & Book and Eskilsson 2000 \\
\hline 14. Renewal of downtown Staffanstorp & Sweden & Book and Eskilsson 2000 \\
\hline 15. Restoring the Llobregat-river in Barcelona & Spain & Junyent 2000 \\
\hline 16. Port expansion in Barcelona & Spain & Junyent 2000 \\
\hline 17. Airport expansion in Barcelona & Spain & Junyent 2000 \\
\hline
\end{tabular}

The procedure of choosing the cases consisted of a broad study of literature, whereas published studies on the one hand and grey literature of research cooperations on the other hand were screened. This search led to a total of seventeen case studies which were considered for the analysis on the basis of these criteria (cf. Table 1$)^{2}$. The selection criteria focused on the aptitude of the examined case for the interrogation, and not on the cases themselves. This means that the case studies had to be comparative, and not the issues that were examined. These are, in accordance, not homogenous. Studies of great urban regions, such as Barcelona and Marseille, as well as those of smaller urban regions, such as Groningen and Freiburg, are used. In addition, there exists no even distribution among the framework of European countries. Although the comparability of the studies is assured by the selection criteria, this selection can obviously neither claim to be complete nor representative. This circumstance is taken into account by the choice of method being presented in the following.

These seventeen case studies will be systematically compared in the following. The four postulates for each model being tested can be understood as coherent groups of interdependent, institutionally influencing factors. The empirical section focuses on the combined effects of the institutional characteristics. Hereunto, the method of the Qualitative Comparative Analysis (QCA) is applied (De Meur and Rihoux 2002; Ragin 1987, 2000; Wagschal 1999, p. 291), which is especially applicable when comparing a medium range of cases. QCA is based on the basic principles of Boolean algebra which oper-

2 See Sager (2002, S. 254-280) for the presentation of all considered cases. 
Table 2: Operationalisation of the dependent variables/results

\begin{tabular}{|c|c|c|c|c|}
\hline \multirow[t]{2}{*}{ Results } & \multirow{2}{*}{\multicolumn{2}{|c|}{$\begin{array}{ll}\text { Given } & \text { Mostly given } \\
& \text { Code } 1 \\
\end{array}$}} & Mostly not given & Not given \\
\hline & & & \multicolumn{2}{|c|}{$\begin{array}{c}\text { Code 0 } \\
\end{array}$} \\
\hline $\begin{array}{l}\text { Coordination } \\
\text { symbol: } K\end{array}$ & $\begin{array}{l}\text { - Adaptation of players' } \\
\text { mindset occurs }\end{array}$ & - & - & $\begin{array}{l}\text { - Adaptation } \\
\text { of players' } \\
\text { mindset does } \\
\text { not occur }\end{array}$ \\
\hline $\begin{array}{l}\text { Formal } \\
\text { rationality } \\
\text { symbol: } F\end{array}$ & $\begin{array}{l}\text { - Coordination is } \\
\text { voluntary } \\
\text { - Coordination is posi- } \\
\text { tive, i.e. multilateral } \\
\text { - Ethics of responsibil- } \\
\text { ity dominates }\end{array}$ & $\begin{array}{l}\text { - Coordination is } \\
\text { negotiated }\end{array}$ & $\begin{array}{l}\text { - Coordination } \\
\text { is superim- } \\
\text { posed and not } \\
\text { negotiated }\end{array}$ & $\begin{array}{l}- \text { No } \\
\text { coordination }\end{array}$ \\
\hline $\begin{array}{l}\text { Substantial } \\
\text { rationality } \\
\text { symbol: } S\end{array}$ & $\begin{array}{l}\text { - The solution found } \\
\text { gratifies the interests } \\
\text { of all involved, i.e. the } \\
\text { benefit of the winner } \\
\text { suffices for the com- } \\
\text { pensation of the loser }\end{array}$ & $\begin{array}{l}\text { The benefit for } \\
\text { the winner par- } \\
\text { tially suffices for } \\
\text { the compensa- } \\
\text { tion of the loser }\end{array}$ & - & $\begin{array}{l}\text { The benefit } \\
\text { for the win- } \\
\text { ner is a loss } \\
\text { to the loser }\end{array}$ \\
\hline $\begin{array}{l}\text { Implementation } \\
\text { symbol: } U\end{array}$ & $\begin{array}{l}\text { - The solution found is } \\
\text { implemented }\end{array}$ & $\begin{array}{l}\text { - The solution } \\
\text { found is mostly } \\
\text { implemented }\end{array}$ & $\begin{array}{l}\text { - The solution } \\
\text { found is mostly } \\
\text { not implemented }\end{array}$ & $\begin{array}{l}\text { - The solution } \\
\text { found is not } \\
\text { implemented }\end{array}$ \\
\hline
\end{tabular}

ates with the binary system. One precondition for applying QCA is using solely binary encoded variables.

The dichotomization associates a loss of information. Nevertheless, it was refrained from using a finer levelled encoding, which could have been interpreted with the enhancement of the QCA, the so-called Fuzzy Sets (fsQCA). A finer levelled encoding would have increased the danger of arbitrary encoding, especially since the cases are qualitative case studies of different authors. The following operationalisation aims at a clear, qualitative threshold value to distinguish the presence of a value (code 1) from its absence (code 0 ). In this manner, the cases were encoded in a standardized way along the operationalisation of policy coordination (Table 2), as in each of the four organizational dimensions (Table 3).

Table 2 shows the operationalisation of the four dependent variables.

The four described dimensions of organisation can be operationalised as independent variables or preconditions for the present study. In each variable both schools feature different values. Table 3 presents the operationalisation of the independent variables.

The values of the variables are partly distorted, since the cases are not equally distributed among the European countries, and since the variables are partly dependent upon the constitutional context. The QCA meets this challenge with the logic of the Boolean algebra. The Boolean addition functions with the logical operator "or", i.e. if two variables $A$ and $B$ signify 1 and the result $Z$ is also 1 , then the coherence $A+B=Z$ is applied, resulting in $1+1=1$ with the applied values. The result is also $Z=1$ if only $A$ or only $B$ has the value 1 , this means that $0+1=1$ and $1+0=1$. The Boolean multiplication, contrary to addition, applies the logical operator "and", thus according with conventional 
Table 3: Operationalisation of independent variables/preconditions

\begin{tabular}{|c|c|c|}
\hline Precondition & Neoprogressive model & Public choice model \\
\hline & $\begin{aligned} \text { Code } 1 \\
\end{aligned}$ & $\begin{array}{r}\text { Code 0 } \\
\end{array}$ \\
\hline $\begin{array}{l}\text { Degree of } \\
\text { centralization }\end{array}$ & $\begin{array}{l}\text { - Hierarchical project structure } \\
\text { - In the hierarchy of the responsible } \\
\text { government office high project } \\
\text { management } \\
\text { - Primus inter pares position with } \\
\text { central coordination tasks in the } \\
\text { responsible coordinating body within } \\
\text { the administration }\end{array}$ & $\begin{array}{l}\text { - Flat project structure } \\
\text { - In the hierarchy of the respon- } \\
\text { sible government office low } \\
\text { project management } \\
\text { - The responsible coordinating } \\
\text { body within the administration in } \\
\text { the function of a site of free com- } \\
\text { munication without any central } \\
\text { switch point }\end{array}$ \\
\hline $\begin{array}{l}\text { Degree of } \\
\text { consolidation }\end{array}$ & $\begin{array}{l}\text { - Status of agglomeration as a political } \\
\text { unit, resp. as a separate federal level } \\
\text { (region, district) }\end{array}$ & $\begin{array}{l}\text { - No status of agglomeration as } \\
\text { a political unit: core municipal- } \\
\text { ity with equal agglomeration } \\
\text { communities }\end{array}$ \\
\hline $\begin{array}{l}\text { Degree of } \\
\text { professionalisation }\end{array}$ & $\begin{array}{l}\text { - No influence of the non-profes- } \\
\text { sional administrations of suburban } \\
\text { communities for the process of } \\
\text { decision-making } \\
\text { - Tasks demanding professional exper- } \\
\text { tise are conducted primarily by the } \\
\text { administration }\end{array}$ & $\begin{array}{l}\text { - The non-professional administra- } \\
\text { tion of suburban communities } \\
\text { have influence on the process of } \\
\text { decision-making } \\
\text { - Tasks demanding profes- } \\
\text { sional expertise are primarily } \\
\text { outsourced }\end{array}$ \\
\hline $\begin{array}{l}\text { Degree of political } \\
\text { autonomy }\end{array}$ & $\begin{array}{l}\text { - The political area is divided from the } \\
\text { technical area }\end{array}$ & $\begin{array}{l}\text { - The political area and the techni- } \\
\text { cal area are not clearly divided }\end{array}$ \\
\hline
\end{tabular}

binary variables of multiplication. The idea of QCA is to create so-called truth tables for the found values of the examined conditions, in which the observed combination of factors are combined. The configurations will be subsequently transcribed into additive and multiplicative formulas, whereas value 1 will be marked with capital letters, the value 0 with lower case letters.

The case number of each observed source configuration is secondary, which is why the mentioned unequal distribution of the cases does not pose a problem. Cases lacking data will not be considered. In two steps, redundant variables will be eliminated from the formalized data of the truth tables using a minimizing algorithm (Quine-McCluskey algorithm). This is to attain a definition of the dependent variables which contains a number of influential factors in specific combinations. This analysis will be applied in the following section for each of the four dependent variables.

Table 4 offers an overview of the data obtained from binary encoding of the seventeen test cases.

\section{Results}

The results of the analysis using QCA will be presented along the four dependent variables. 


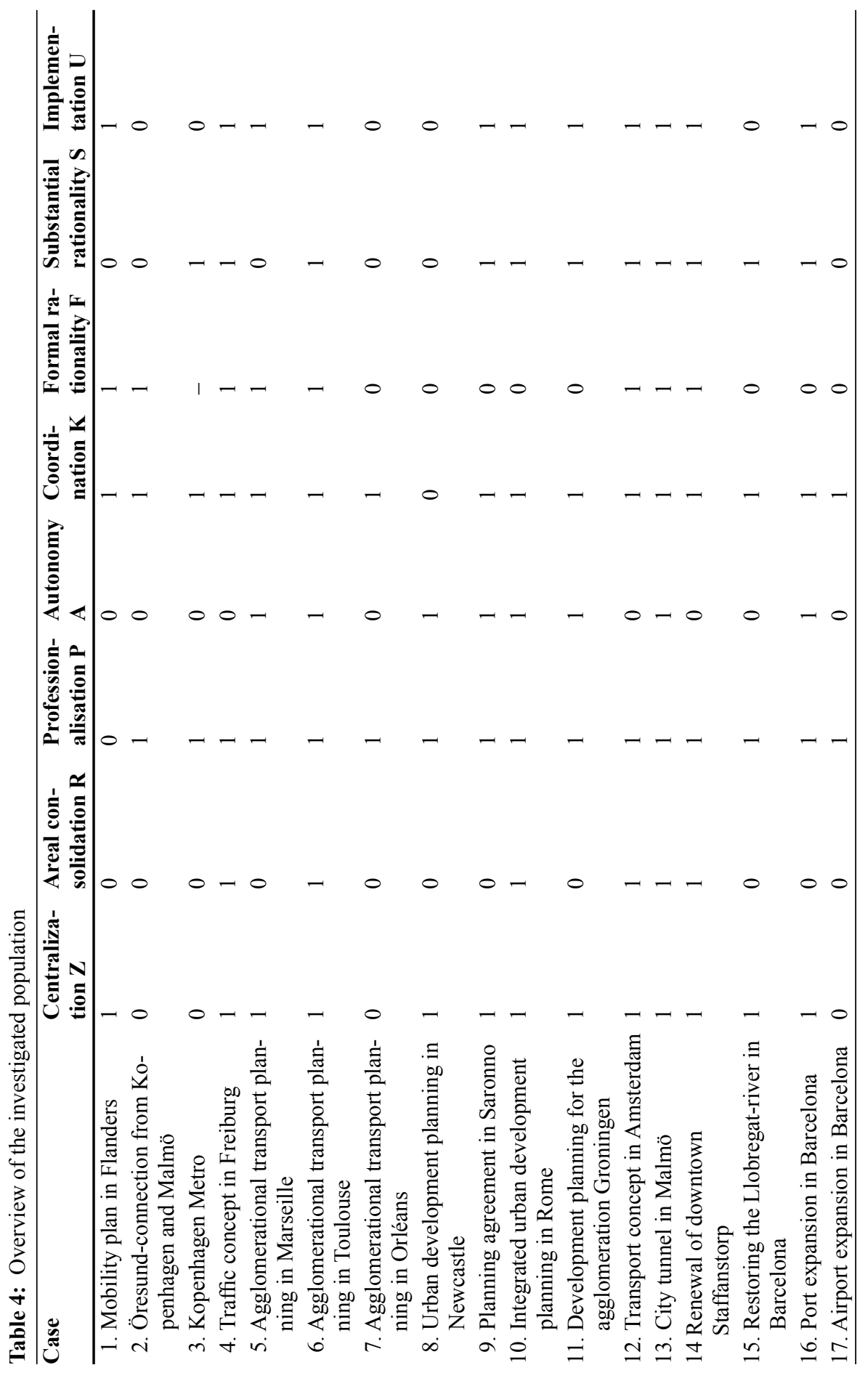




\subsection{Institutional configurations for establishing coordination}

The population offers six constellations of the four conditions for the dependent size "coordination" out of sixteen possible combinations $\left(4^{2}\right)$. One constellation is derived from both results: the combination $\mathrm{ZrPA}$ leads to coordination in four of the examined cases (cases 5, 9, 11 and 16), in one case (case 8), however, it did not. Ragin (1987, p. 116) provides several alternatives in dealing with such contradictory cases. The seemingly useful alternative encodes the outcome of two ambiguous combinations with 0 and only includes constellations for an outcome of 1 if they are distinct ${ }^{3}$. The information derived from the encoded case studies can be transmitted into the following formula:

$$
\mathrm{K}=\mathrm{zrPa}+\mathrm{Zrpa}+\mathrm{ZrPa}+\mathrm{ZRPa}+\mathrm{ZRPA}
$$

This result will be reduced to the core variables in a step-by-step operation. The core solution, which cannot be further minimized, is:

$$
\mathrm{K}=\mathrm{Zra}+\mathrm{ZRP}+\mathrm{rPa}
$$

The result of the QCA is accordingly: a process of coordination occurs, when

a) a centralized organisation and fragmented urban area and a minor autonomy of the administration exist, or

b) a centralized organisation and a consolidated urban structure and a high professionalization exist, or

c) a fragmented urban structure and a high professionalization and a minor autonomy of the administration exist.

The defined result indicates that none of the four examined variables fulfil the required and sufficient conditions for establishing coordination, because none of the factors occur in all conditions, nor do they solely result in coordination. The result implicates neither the neoprogressive model nor the public choice model. It rather depends on the particular factors of configuration, whether the preconditions are liable to have a positive effect on the occurrence of coordination.

\subsection{Institutional configurations for formal rationality}

Six configurations are found for the dependent value of formal rationality $(\mathrm{F})$, of which three are contradictory and will therefore be eliminated. Of the three distinct configurations, two lead to formal rational coordination negotiations (F). Contrary to that, decreed coordination (f) is the result of only one definite configuration. The data can be transmitted into the following equation:

$$
\mathrm{F}=\mathrm{Zrpa}+\mathrm{ZRPa}
$$

3 The second alternative is transcoding into a non-existent combination. This arbitrary approach will be neglected. The third alternative is a unified encoding of the outcome with 1 , leading to several solutions, but being difficult to interpret (Ragin 1987, S. 116). 
No implicants can be generated out of this equation. But the equation can be circumscribed as:

$$
\mathrm{F}=\mathrm{Za}(\mathrm{rp}+\mathrm{RP})
$$

Formal rational coordination can therefore be observed in cases with a centralized organizational structure and a minor autonomy of the administration and

a) with either a fragmented urban area and a minor professionalization or

b) with a consolidated urban area and a high professionalization exist.

The parameter values 'high degree of centralization' and 'low degree of autonomy' present a necessary condition, but are not sufficient, since they only lead to formal rational coordination negotiations in combination with the two remaining variables. The two remaining variables possess neither the necessary, nor the sufficient properties.

Consolidated urban structures have a positive effect on formal rational coordination if a high centralization of the institutional frame, a high professionalization and a minor autonomy of administration simultaneously exist. In contrast, formal rational coordination also occurs in fragmented structures, but only if a low professionalization is to be observed at the same time. In both cases, the horizontal integration of the institutional frame plays a primary role. Centralization supports formal rationality, or can even compensate it. One other result shows that a politically dependent administration will initiate formal rational coordination negotiations rather than an apolitical one. In rather technocratically organized Western European political systems with very strong urban administrations, a higher consideration for political interests obviously increases the process quality of policy coordination.

\subsection{Institutional configuration for establishing substantial rationality}

The case studies contain six different configurations for the dependent value substantial rationality $(\mathrm{S})$, two of which are contradictory and lead to a negative result. In contrast, three configurations lead to substantial rationality, the initial equation being:

$$
\mathrm{S}=\mathrm{ZrPa}+\mathrm{ZRPa}+\mathrm{ZRPA}
$$

Two implicants can be formed out of this equation. The minimized equation is:

$$
\mathrm{S}=\mathrm{ZPa}+\mathrm{ZRP}
$$

The equation, in turn, can be circumscribed as

$$
\mathrm{S}=\mathrm{ZP}(\mathrm{a}+\mathrm{R})
$$

Substantial rationality is therefore achieved if a centralized organizational structure and a high professionalization occur, and

a) either a minor autonomy of administration, or

b) a consolidated urban area exists. 
It is shown that in order to achieve substantially rational results, two parameter values are necessary: a high centralization and a high professionalization, whereas the two remaining variables do not necessarily need to occur. Neither of these variables offers a sufficient source for substantial rationality.

With the exception of the effect of the political affiliation of administration, the results accord with the neoprogressive postulates. As with formal rationality, the positive effect of minor autonomy can be explained with the generally few possibilities of participation in European cities. Comparing professionalization and autonomy, it must be emphasized that professionalization is a necessary and therefore a more important precondition for substantially rational solutions, whereas autonomy is a replaceable condition and is therefore second-ranking.

\subsection{Institutional configurations for implementation}

Six configurations occur for the dependent value implementation, one of which is contradictory and two lead to a negative outcome. Three configurations will therefore be factored into the QCA, which can be transferred into the following equation:

$$
\mathrm{U}=\mathrm{Zrpa}+\mathrm{ZRPa}+\mathrm{ZRPA}
$$

By combining ZRPa and ZRPA to ZRP, the equation can be minimized as follows:

$$
\mathrm{U}=\mathrm{Zrpa}+\mathrm{ZRP}
$$

Since this result cannot be further reduced, the QCA states that a realization of coordinated planning occurs where

a) a centralized organization and a fragmented urban area and a low professionalization and a minor autonomy of administration occur,

or

b) a centralized organization and a consolidated urban area and a high professionalization exist.

The solution of the QCA is of special interest, since it defines the same result with two contradictory constellations, depending on whether a further parameter value occurs or not. To be precise, an implementation occurs when the necessary term 'high centralization' occurs by fragmented and consolidated urban structures, as well as by high and low professionalization. It solely depends on whether the administration is politically dependent or not.

In addition to the hitherto results, which mostly speak for the neoprogressive assumptions, it is shown that implementation occurs even under contradictory terms of these postulates. These will, however, be much stronger politicized as in consolidated areas with highly professionalized structures. The interpretation is therefore permissible that in consolidated areas improvements of the spatial situation are found primarily using tech- 
nical expertise solutions. Contrary to that, these improvements in fragmented areas are found using politically dominated solutions, not solely technically legitimate ones.

\subsection{When are substantially rational solutions implemented?}

After discussing each dependent value separately, this section will deal with the question under which circumstances substantially rational solutions will be implemented. To answer this question, the dataset was complemented with the new variable implementation I. It has the value 1 if a substantial rational solution is implemented and the value 0 if a substantial rational solution is not implemented. Eleven cases feature one of the two values of the variable and can therefore be evaluated. The Boolean value table (Table 5) shows five cause configurations, all of which are definite. Two configurations do not lead to implementation, three lead to implementation.

In a first step, all configurations leading to implementation can be transmitted into an equation:

$$
\mathrm{I}=\mathrm{ZrPA}+\mathrm{ZRPa}+\mathrm{ZRPA}
$$

The maximally reduced formula is:

$$
\mathrm{I}=\mathrm{ZPA}+\mathrm{ZRP}
$$

This solution definitely supports the neoprogressive model pertaining to the question when substantially rational solutions are implemented. A realization occurs if a high degree of centralization of the organization and a high professionalization and

a) a high autonomy of the technical administration, or

b) a high degree of consolidation exists.

In a second step the question will be when a substantially rational solution is not realized. The Boolean value table contains the two following configurations:

$$
\mathrm{i}=\mathrm{zrPa}+\mathrm{ZrPa}
$$

Both configurations can be merged to the implicant $\mathrm{rPa}$, since the value $\mathrm{Z}$ is of no significance to the outcome. Ensuing:

$$
\mathrm{i}=\mathrm{rPa}
$$

The QCA solution also shows that the combination of fragmented urban structure and a high degree of professionalization and a minor autonomy of administration present a

Table 5: Boolean value table for the dependent factor implementation I

\begin{tabular}{llllll}
\hline $\begin{array}{l}\text { Centraliza- } \\
\text { tion Z }\end{array}$ & $\begin{array}{l}\text { Urban consoli- } \\
\text { dation R }\end{array}$ & $\begin{array}{l}\text { Professionali- } \\
\text { zation } \mathbf{P}\end{array}$ & Autonomy A & $\begin{array}{l}\text { Implementa- } \\
\text { tion I }\end{array}$ & $\begin{array}{l}\text { Case number } \\
\text { N }\end{array}$ \\
\hline 0 & 0 & 1 & 0 & 0 & 1 \\
1 & 0 & 1 & 0 & 0 & 1 \\
1 & 1 & 1 & 1 & 3 \\
1 & 0 & 1 & 0 & 1 & 3 \\
1 & 1 & 1 & 1 & 3 \\
\hline
\end{tabular}


necessary and sufficient circumstance under which a substantially rational solution is not realized.

In both results, the neoprogressive model is more successful regarding the realization of coordinated policy solutions. A high degree of centralization or strong expertise knowledge are necessary factors for a positive result either in combination with consolidated urban areas, or with a high autonomy of administration - all of which signify neoprogressive postulates. Configurations which prevent implementation prove to be an effective mutual blockade of neoprogressive and public choice postulates. It is of special interest that this configuration $\mathrm{rPa}$, predominantly in the equation (1.2), was identified at all as a possible condition for realizing coordination. Thus, the success of coordination processes regarding decisions and implementation is not ensured solely due to their presence. In fact, the same source configuration may lead to coordination processes on the one hand, but may prevent the realization of substantially rational solutions on the other.

No source configuration combines public choice postulates efficiently regarding establishing coordinated solutions in any of the cases. Therefore, in this comparison, the neoprogressive model is considered to have better preconditions for realizing substantially rational planning decisions, and therefore for "establishing and stabilizing a collective capacity to act" (Schimank 2002, p. 31).

\section{Conclusion}

The present essay interrogated the institutional conditions for a collective capacity to act in urban areas. The empirical results out of comparing seventeen case studies of decision-making processes in spatial and transport planning of Western European urban areas conclude that the neoprogressive model is the more successful of the two analyzed administration models. This is exemplarily shown using substantially rational solutions as a measurement for successfully solved problems of interdependence. A high degree of organizational centralization of the project structures and a high degree of professionalization of the involved players prove to be a necessary precondition for realizing solutions in the analysis. These solutions comply with the Kaldor optimum, because the use for the beneficiaries is large enough to compensate all players disadvantaged by the method. Additionally, a high autonomy of administration or a high degree of consolidation must exist. Substantially rational solutions will be more likely implemented if developed under institutional preconditions which are in accordance with the postulates of the neoprogressive school.

The complexity of institutional interdependency ascertained in the QCA does not suggest any institutional ready-to-use solution regarding institutional reforms in metropolitan areas which could lead to a total reform of existing organizational arrangements with the "golden ratio". It rather suggests the inductive approach for each step concerning specific problems. At the same time, the results speak for a certain rehabilitation of the classical administration in the sense of a vertical, differentiated organizational line with hierarchical control mechanisms. As the cases have shown, coordination costs can be reduced and conflicts prevented with hierarchical decision-making. Overall welfare-maximizing solutions will therefore be achieved with less effort, and they possess a higher political acceptance. 
These statements are somewhat contrary to the current mainstream of administrative science, which opts for an extensive breaking up of hierarchies and establishing horizontal market situations between each administration office. Especially concerning policy coordination, it should be considered that the propagated market mechanisms from political-economical reform models, such as the New Public Management, convey less cooperative, but more autarkic acting. Economical efficiency views lead in their own logic to more competition than to cooperation, and therefore contradict the coordination between policy fields, as well as between territorial units.

\section{References}

Benz, Arthur. 1994. Kooperative Verwaltung. Funktionen, Voraussetzungen und Folgen. BadenBaden: Nomos.

Berg-Schlosser, Dirk. 1997. Makro-qualitative vergleichende Methoden. In Vergleichende Politikwissenschaft, ed. Dirk Berg-Schlosser, and Ferdinand Müller-Rommel, 67-88. Opladen: Leske+Budrich.

Berg-Schlosser, Dirk, and Sven Quenter. 1996. Makro-quantitative vs. makro-qualitative Methoden in der Politikwissenschaft - Vorzüge und Mängel komparativer Verfahrensweisen am Beispiel der Sozialstaatstheorie. Politische Vierteljahresschrift 1(37):100-18.

Blatter, Joachim. 2005. Metropolitan governance in Deutschland: Normative, utilitaristische, kommunikative und dramaturgische Steuerungsansätze. Swiss Political Science Review 1(11):119-55.

Book, Karin, and Lena Eskilsson. 2000. Co-ordination between transport and land-use planning in the expansive scania region. In COST 332 - transport and land-use policies: Innovations in institutional arrangements for co-ordination. Final report of the action, ed. European Commission, 117-35. ftp://ftp.cordis.europa.eu/pub/cost-transport/docs/332-en.pdf. Accessed 07 Nov 2007.

Bratzel, Stefan. 1999. Erfolgsbedingungen umweltorientierter Verkehrspolitik in Städten. Analysen zum Policy-Wandel in den, relativen Erfolgsfällen 'Amsterdam, Groningen, Zürich und Freiburg (i. Brg.). Basel: Birkhäuser.

Budäus, Dietrich. 1994. Public Management. Konzepte und Verfahren zur Modernisierung öffentlicher Verwaltungen. Berlin: Ed. Sigma.

Caramani, Daniele, ed. 2005. Images of Europe: Cultural diversity and European integration. London: Routledge.

De Meur, Gisèle et Benoît Rihoux. 2002. L'analyse quali-quantitative comparée (AQQCQCA). Approches, techniques et applicatoins en sciences humaines. Louvain-la-Neuve: BruylantAcademia.

Dijst, Martin, and Walter Schenkel. 2002. Urban performance in perspective. In Governing cities on the move. functional and management perspectives on transformations of European agglomerations, eds. Martin Dijst, Walter Schenkel, and Isabelle Thomas, 1-18. Ashgate: Aldershot.

Downs, Anthony. 1957. An economic theory of democracy. New York: Harper and Brothers.

Glass, Gene V., Barry Mac Gaw, and Mary Lee Smith. 1994. Meta-analysis in social research. Beverly Hills, CA: Sage.

Goodsell, Charles T. 1994. The case for bureaucracy. A public administration polemic. Chatham, New Jersey: Chatham House Publishers.

Guy, Simon, Robert Evans, and Simon Marvin. 2000. Views of the city: Multiple pathways to sustainable transport futures. In COST 332 - transport and land-use policies: Innovations in institutional arrangements for co-ordination. Final Report of the Action, ed. European Commission, 235-47. ftp://ftp.cordis.europa.eu/pub/cost-transport/docs/332-en.pdf. Accessed 07 Nov 2007. 
Haas, Ernst B. 1964. Beyond the nation-state: Functionalism and international organization. Stanford: Stanford University Press.

Haas, Peter M. 1992. Introduction: Epistemic communities and international policy coordination. International Organization 1(46):1-35.

Hay, Colin. 2004. Theory, stylized heuristic or self-fulfilling prophecy? The Status of rational choice theory in public administration. Public Administration 1(82):39-62.

Heinz, Werner, ed. 2000. Stadt und Region: Kooperation oder Koordination? Ein internationaler Vergleich. Stuttgart, Berlin, Köln: Kohlhammer.

Hill, Larry B. 1991. Who governs the American administrative state? A bureaucratic-centered image of governance. Journal of Public Administration Research and Theory 3(1):261-94.

Holz-Rau, Christian, and Ute Jansen. 2007. Nachhaltige Raum- und Verkehrsplanung. Aus Politik und Zeitgeschichte 29-30:21-6.

Hunter, John E., and Frank L. Schmidt. 1990. Methods of meta-analysis. Newbury Park, CA: Sage.

Janssen-Jansen, Leonie B. 2005. Beyond sprawl: Principles for achieving more qualitative spatial development. DISP 160(41):36-41.

Jones, Bryan D. 2003. Bounded rationality and political science: Lessons from public administration and public policy. Journal of Public Administration Research and Theory 4(13):395-421.

Junyent, Rosa. 2000. Actors in co-ordination for the construction of transport infrastructures in barcelona. The delta plan. In COST 332 - transport and land-use policies: Innovations in institutional arrangements for co-ordination. Final report of the action, ed. European Commission, 137-51. ftp://ftp.cordis.europa.eu/pub/cost-transport/docs/332-en.pdf. Accessed 07 Nov 2007.

Kaelble, Hartmut. 2002. The historical rise of a European public sphere. Journal of European Integration History 2(8):9-22.

Kaldor, Nicholas. 1939. Welfare propositions of economics and inter-personal comparisons of utility. The Economic Journal 195(49):549-52.

Kaufmann, Vincent, and Fritz Sager. 2006. The coordination of local policies for urban development and public transportation in four Swiss cities. Journal of Urban Affairs 4(28):353-74.

Keating, Michael. 1995. Size, efficiency and democracy: Consolidation, fragmentation and public choice. In Theories of urban politics, eds. David Judge, Gerry Stoker, and Harold Wolman, 117-34. London: Sage Publications.

Kettl, Donald F. 2000. The global public management revolution: A report on the transformation of governance. Washington, D.C.: Brookings Institution Press.

Knill, Christoph. 1999. Explaining cross-national variance in administrative reform: Autonomous versus instrumental bureaucracies. Journal of Public Policy 2(19):113-39.

Krücken, Georg. 2002. Amerikanischer Neo-Institutionalismus - europäische Perspektiven. Sociologia Internationalis 40:227-59.

Lane, Jan-Erik. 2000. New public management. London: Routledge.

Le Galès, Patrick. 1998. Regulation and governance in European cities. International Journal of Urban and Regional Research 3(22):482-506.

Lefèvre, Christian. 1998. Metropolitan government and governance in Western Countries: A Critical Review. International Journal of Urban and Regional Research 1(22):9-25.

Lowery, David. 1999. Answering the public choice challenge: A neoprogressive research agenda. Governance 1(12):22-53.

Lyons, William E., David Lowery, and Ruth Hoogland de Hoog. 1992. The politics of dissatisfaction. Citizens, services, and urban institutions. Armonk, NY: M. E. Sharpe.

Margail, Fabienne, and Jean-Marc Offner. 2000. The urban road planning studies: A state procedure dedicated to co-ordination and coherence. In COST 332 - transport and land-use policies: Innovations in institutional arrangements for co-ordination. Final report of the action, ed. European Commission, 153-73. ftp://ftp.cordis.europa.eu/pub/cost-transport/docs/332-en.pdf. Accessed 07 Nov 2007. 
Matthiessen, Christian W. 2000. The oresund region. Large scale cross boundary infrastructure as a driving force behind organisational change: regional integration. In COST 332 - transport and land-use policies: Innovations in institutional arrangements for co-ordination. Final report of the action, ed. European Commission, 93-115. ftp://ftp.cordis.europa.eu/pub/cost-transport/ docs/332-en.pdf. Accessed 07 Nov 2007.

Morandi, Corinna, Anna Moretti, and Paola Tessitore. 2000. The programme agreement of Saronno- Lombardy. In COST 332 - transport and land-use policies: Innovations in institutional arrangements for co-ordination. Final report of the action, ed. European Commission, 175-202. ftp://ftp.cordis.europa.eu/pub/cost-transport/docs/332-en.pdf. Accessed 07 Nov 2007.

Nigro, Felix A., and Lloyd G. Nigro. 1989. Modern public administration. New York: Harper \& Row.

Nijkamp, Peter, Marc Van DerBurch, and Gabriella Vindigni. 2002. A comparative institutional evaluation of public- private partnerships in Dutch urban land-use and revitalisation projects. Urban Studies 10(39):1865-880.

Niskanen, William A. 1971. Bureaucracy and representative government. Chicago: Aldine Transaction.

Obinger, Herbert. 1998. Politische Institutionen und Sozialpolitik in der Schweiz. Der Einfluss von Nebenregierungen auf Struktur und Entwicklungsdynamik des schweizerischen Sozialstaates. Frankfurt a.M., New York: Lang.

Osborne, David, and Ted Gaebler. 1992. Reinventing government: How the enterpreneurial spirit is transforming the public sector. Reading, MA: Addison-Wesley.

Ostrom, Vincent, and Elinor Ostrom. 1971. Public choice: A different approach to public administration. Public Administration Review 2(31):203-16.

Ostrom, Vincent, Robert L. Bish, and Elinor Ostrom. 1988. Local government in the United States. San Francisco: Institute for Contemporary Studies.

Powell, Walter W., and Paul J. Di Maggio, eds. 1991. The new institutionalism in organizational analysis. Chicago: University of Chicago Press.

Ragin, Charles C. 1987. The comparative method. Moving beyond qualitative and quantitative strategies. Berkely: University of California Press.

Ragin, Charles C. 2000. Fuzzy-set social science. Chicago: University of Chicago Press.

Raphael, Lutz. 2000. Recht und Ordnung. Herrschaft durch Verwaltung im 19. Jahrhundert. Frankfurt a.M.: Fischer.

Sager, Fritz. 2002. Vom Verwalten des urbanen Raums. Institutionelle Bedingungen von Politikkoordination am Beispiel der Raum- und Verkehrsplanung in städtischen Gebieten. Bern: Haupt.

Sager, Fritz. 2005. Metropolitan institutions and policy coordination. The integration of land use and transport policies in Swiss urban areas. Governance. An International Journal of Policy, Administration, and Institutions 2(18):227-56.

Scharpf, Fritz W. 1972. Komplexität als Schranke der politischen Planung. Politische Vierteljahresschrift, Sonderheft 4 , Gesellschaftlicher Wandel und politische Innovation‘. 168-92.

Scharpf, Fritz W. 1991: Die Handlungsfähigkeit des Staates am Ende des zwanzigsten Jahrhunderts. Politische Vierteljahresschrift 32(4):621-34.

Scharpf, Fritz W. 1992. Einführung. Zur Theorie von Verhandlungssystemen. In Horizontale Politikverflechtung. Zur Theorie von Verhandlungssystemen, eds. Arthur Benz, Fritz W. Scharpf, and Reinhard Zintl, 11-28. Frankfurt a.M.: Campus.

Scharpf, Fritz W. 1993. Positive und negative Koordination in Verhandlungssystemen. In PolicyAnalyse. Kritik und Neuorientierung. PVS Sonderheft 24, ed. Adrienne Héritier, 57-83. Opladen: Westdeutscher Verlag.

Scharpf, Fritz W. 1994. Games real actors could play. Positive and negative coordination in embedded negotiations. Journal of Theoretical Politics 1(6):27-53.

Scharpf, Fritz W. 1997. Games real actors play. Actor-centered institutionalism in policy research. Boulder, Oxford: Westview Press. 
Schedler, Kuno. 1995. Ansätze einer wirkungsorientierten Verwaltungsführung. Von der Idee des New Public Management (NPM) zum konkreten Gestaltungsmodell. Fallbeispiel Schweiz. Bern: Haupt.

Schimank Uwe, 2002. Organisationen. Akteurkonstellationen - korporative Akteure - Sozialsysteme. In Organisationssoziologie, Kölner Zeitschrift für Soziologie und Sozialpsychologie, Sonderheft 42, eds. Jutta Allmendinger, and Thomas Hinz, 29-54. Opladen,Wiesbaden: Westdeutscher Verlag.

Schneider, Carsten Q., and Claudius Wagemann. 2007. Qualitative Comparative Analysis (QCA) und Fuzzy-Sets. Ein Lehrbuch für Anwender und alle, die es werden wollen. Leverkusen, Opladen: Verlag Barbara Budrich.

Scott, W. Richard, and John W. Meyer. 1991. The Organization of societal sectors: Propositions and early evidence. In The new institutionalism in organizational analysis, eds. Walter W. Powell, and Paul J. Di Maggio, 108-42. Chicago, London: University of Chicago Press.

Sessa, Carlos, and Mario Gualdi. 2000: Transport and land-use co-ordination: Innovative policies in Rome. In COST 332 - transport and land-use policies: Innovations in institutional arrangements for co-ordination. Final report of the action, ed. European Commission, 269-87. ftp:// ftp.cordis.europa.eu/pub/cost-transport/docs/332-en.pdf. Accessed 07 Nov 2007.

Simon, Herbert A. 1962. The architecture of complexity. Proceedings of the American Philosophical Society 106:467-82.

Steenberghen, Thérèse. 2000. Mobility covenants between local authorities, public transport comanies and the regional authority in flanders (Belgium). In COST 332 - transport and land-use policies: Innovations in institutional arrangements for co-ordination. Final report of the action, ed. European Commission, 221-33. ftp://ftp.cordis.europa.eu/pub/cost-transport/docs/332en.pdf. Accessed 07 Nov 2007.

Tiebout, Charles M. 1956. A pure theory of local expenditures. Journal of Political Economy 5(64):416-24.

Voogd, Henk. 2000. Co-ordination between transport planning and land-use planning: Some Dutch experiences. In COST 332 - transport and land-use policies: Innovations in institutional arrangements for co-ordination. Final report of the action, ed. European Commission, 203-19. ftp://ftp.cordis.europa.eu/pub/cost-transport/docs/332-en.pdf. Accessed 07 Nov 2007.

Wagschal, Uwe. 1999. Statistik für Politikwissenschaftler. München, Wien: Oldenbourg.

Weber, Max. (1972/1922). Wirtschaft und Gesellschaft. Grundriss der verstehenden Soziologie. Tübingen: Mohr.

West, William F. 1995. Controlling the bureaucracy. Institutional constraints in theory and practice. Armonk, London: M. E. Sharpe.

Wilson, Woodrow. 1887. The study of administration. Political Science Quarterly 2:197-222.

Wittek, Rafael, and Andreas Flache. 2002. Rational Choice und Organisationstheorie. In Organisationssoziologie, Kölner Zeitschrift für Soziologie und Sozialpsychologie, Sonderheft 42, eds. Jutta Allmendinger, and Thomas Hinz, 55-87. Opladen: Westdeutscher Verlag.

Wolf, Fredric Marc. 1986. Meta-analysis: Quantitative methods for research synthesis. Beverly Hills, CA: Sage Publications.

Wolf, Patrick J. 1993. A case survey of bureaucratic effectiveness in U.S. Cabinet agencies: Preliminary results. Journal of Public Administration Research and Theory 2(3):161-81.

Zucker, Lynne G. 1983. Organizations as institutions. In Research in the sociology of organizations, ed. Samuel B. Bachrach, 1-42. Greenwich, Conn.: JAI Press. 